\title{
Mouse 17 $\beta$-hydroxysteroid dehydrogenase type 2 mRNA is predominantly expressed in hepatocytes and in surface epithelial cells of the gastrointestinal and urinary tracts
}

\section{V J Mustonen, M H Poutanen, S Kellokumpu' ${ }^{1}$ Y de Launoit ${ }^{2}$, V V Isomaa, $\mathbf{R} \mathbf{K}$ Vihko and $\mathbf{P} \mathbf{T}$ Vihko}

\author{
Biocenter Oulu and Department of Clinical Chemistry, University of Oulu, FIN-90220 Oulu, Finland \\ ${ }^{1}$ Department of Anatomy, University of Oulu, FIN-90220 Oulu, Finland \\ ${ }^{2}$ UMR 319, CNRS/Institut Pasteur de Lille, Institut de Biologie de Lille, 1 rue Calmette, \\ 59019 Lille Cedex, France
}

(Requests for offprints should be addressed to P T Vihko, Biocenter Oulu and Department of Clinical Chemistry, University of Oulu, Kajaanintie 50, FIN-90220 Oulu, Finland)

\begin{abstract}
$17 \beta$-Hydroxysteroid dehydrogenase (17HSD) type 2 efficiently catalyzes the conversion of the high activity $17 \beta$-hydroxy forms of sex steroids into less potent 17 -ketosteroids. In the present study in situ hybridization was utilized to analyze the cellular localization of 17HSD type 2 expression in adult male and female mice. The data indicate that 17HSD type $2 \mathrm{mRNA}$ is expressed in several epithelial cell layers, including both absorptive and secretory epithelia as well as protective epithelium. In both males and females, strong expression of 17HSD type 2 was particularly detected in epithelial cells of the gastrointestinal and urinary tracts. The mRNA was expressed in the stratified squamous epithelium of the esophagus, and surface epithelial cells of the stomach, small intestine and colon. The hepatocytes of the liver and the thick
\end{abstract}

limbs of the loops of Henle in the kidneys, as well as the epithelium of the urinary bladder, also showed strong expression of $17 \mathrm{HSD}$ type $2 \mathrm{mRNA}$ in both male and female mice. In the genital tracts, low 17HSD type 2 expression was detected in the seminiferous tubules, the uterine epithelial cells and the surface epithelium of the ovary. Expression of the mRNA was also detected in the sebaceous glands of the skin. The results indicate that in both male and female mice, 17HSD type 2 is expressed mainly in the various epithelial cell types of the gastrointestinal and urinary tracts, and therefore suggest a role for the enzyme in steroid inactivation in a range of tissues and cell types not considered as classical sex steroid target tissues.

Fournal of Molecular Endocrinology (1998) 20, 67-74

\section{INTRODUCTION}

17 $\beta$-Hydroxysteroid dehydrogenases (17HSDs) catalyze the interconversion between neutral and phenolic $17 \beta$-hydroxy and 17 -ketosteroids such as estrone (E1) and estradiol (E2), androstenedione (A-dione) and testosterone (T), 5a-dihydrotestosterone (DHT) and $5 \alpha$-androstanedione $(5 \alpha-$ A-dione). In general, the $17 \beta$-hydroxy forms of sex steroids have at least one order of magnitude higher affinity for estrogen and androgen receptors compared with the corresponding 17-ketosteroids. Hence, 17HSDs catalyze reactions between highly potent sex steroids and the far less potent 17 -keto forms. The following evidence indicates that 17HSD enzymes play a significant role in several steps regulating the availability of the highly active ligands for receptor binding at the target cells. (i) Reductive $17 \mathrm{HSD}$ activity (17-keto to $17 \beta$ hydroxy) catalyzes one of the last steps in the biosynthesis of E2 and $\mathrm{T}$ in the ovaries and the testes respectively. (ii) Oxidative 17HSD-activity (17ß-hydroxy to 17 -keto) is one of the key metabolic reactions involved in the inactivation and excretion of sex steroids from the blood circulation. (iii) $17 \mathrm{HSD}$ enzymes present in steroid hormone target tissues regulate the relative concentrations of $17 \beta$-hydroxy and 17 -keto forms 
of estrogens and androgens locally at the target tissue level.

At present five distinct 17HSD enzymes have been identified in rodents (Ghersevich et al. 1994a, Deyashiki et al. 1995, Normand et al. 1995, Akinola et al. 1996, Nokelainen et al. 1996, Sha et al. 1996, Mustonen et al. 1997), and four have been characterized in humans (Peltoketo et al. 1988, Wu et al. 1993, Geissler et al. 1994, Adamski et al. 1995). Each of the enzymes possesses unique enzymatic properties and has a distinct tissue distribution. Data obtained using rodent and human tissue specimens and cell lines indicate that reductive 17HSD type 1 and type 3 enzymes are principally involved in $\mathrm{E} 2$ and $\mathrm{T}$ biosynthesis in the ovaries and testes respectively (Geissler et al. 1994, Ghersevich et al. 1994a,b, Poutanen et al. 1995, Andersson et al. 1996, Miettinen et al. 1996). In contrast, type 2 and type 4 enzymes exclusively catalyze the opposite reaction, inactivating E2 to E1, and $\mathrm{T}$ to A-dione (Wu et al. 1993, Leenders et al. 1994, Adamski et al. 1995, Normand et al. 1995, Poutanen et al. 1995, Akinola et al. 1996, Andersson et al. 1996, Dieuaide-Noubhani et al. 1996, Miettinen et al. 1996, Mustonen et al. 1997). In addition, DHT is converted to $5 \alpha$-A-dione by the type 2 enzyme (Wu et al. 1993, Elo et al. 1996).

In addition to the oxidation of $\mathrm{E} 2$ and $\mathrm{T}$, the type 4 enzyme also catalyzes $\beta$-oxidation reactions of fatty acids and intermediates of bile acid biosynthesis (Dieuaide-Noubhani et al. 1996, Qin et al. 1997). The enzyme is constitutively expressed in all human and rodent tissues (Adamski et al. 1995, Mustonen et al. 1997), and our recent findings suggest that, when compared with 17HSD type 2, the type 4 enzyme is very inefficient at oxidizing E2 to E1 (Dieuaide-Noubhani et al. 1996, Qin et al. 1997). The data, hence, suggest that, of the 17HSD enzymes characterized to date, the type 2 enzyme is most efficient at converting $17 \beta$-hydroxysteroids into 17-keto forms. Up to now the cellular distribution of 17HSD type 2 has been only superficially characterized (Casey et al. 1994, Delos et al. 1995, Zhang et al. 1996). The present study, performed by utilizing in situ hybridization, shows that $17 \mathrm{HSD}$ type 2 is particularly expressed in numerous epithelial cell populations of the gastrointestinal and urogenital tracts of both male and female mice.

\section{MATERIALS AND METHODS}

\section{Materials}

Radiolabeled $\left[\alpha_{-}{ }^{35} \mathrm{~S}\right] \mathrm{dCTP} \quad(1300 \mathrm{Ci} / \mathrm{mmol})$ was purchased from DupontNEN (Boston, MA, USA).
Non-labeled nucleotides (rATP, rGTP and rUTP) were purchased from Promega (Madison, WI, USA). Restriction enzymes and DNA-modifying enzymes were from New England Biolabs (Beverly, MA, USA) and Boehringer (Mannheim, Germany). GTG agarose was from FCM BioProducts (Rockland, ME, USA) and the RNA ladder was from BRL (Gaithersburg, MD, USA). T7 and SP6 RNA polymerases were from Promega, and proteinase $\mathrm{K}$ and tRNA were from Boehringer. Other reagents not mentioned were purchased either from the Sigma Chemical Co. (St Louis, MO, USA) or Merck AG (Darmstadt, Germany) and were of the highest purity grade available.

\section{Tissue specimens}

In this study, formalin-fixed, paraffin-embedded mouse tissues were used. Tissues excised from adult $\mathrm{BALB} / \mathrm{c}$ male and female mice were briefly washed with PBS, fixed overnight in 4\% paraformaldehydePBS, dehydrated and embedded in paraffin (solidification point $51-53{ }^{\circ} \mathrm{C}$, Merck). Thereafter, $7 \mu \mathrm{m}$ sections were cut and collected on glass slides. The sections were dewaxed with xylene, and before hybridization, reactive aldehyde groups remaining after fixation were eliminated by 10 -min treatment in $0 \cdot 1 \mathrm{M}$ glycine/ $0 \cdot 2 \mathrm{M}$ Tris $\mathrm{HCl}, \mathrm{pH} 7 \cdot 4$.

\section{In situ hybridization}

A $737 \mathrm{bp}$ fragment (nucleotides 584-1320) of mouse 17HSD type 2 cDNA (Mustonen et al. 1997) was cloned in pSP72 plasmid (Promega). Sense and antisense $\left[\alpha-{ }^{35} \mathrm{~S}\right] \mathrm{C}$ TP-labeled RNA probes were transcribed with SP6 and T7 RNA polymerases using linearized plasmids as templates. Before RNA transcription, the protruding 3 '-overhang produced by $\mathrm{SacI}$ was destroyed by incubating the plasmid with Klenow DNA polymerase for $15 \mathrm{~min}$ at $22^{\circ} \mathrm{C}$. Specific activities of the synthesized RNA probes were approximately $5 \times 10^{7}$ c.p.m. $/ \mu \mathrm{l}$.

The in situ hybridization protocol was based on that described by Chotteau-Lelievre et al. (1997), with minor modifications. Briefly, the sections were treated with proteinase $\mathrm{K}(1 \mu \mathrm{g} / \mathrm{ml}$ in $100 \mathrm{mM}$ Tris $\mathrm{HCl}, 50 \mathrm{mM}$ EDTA, $\mathrm{pH} 8.0$ ) for $15 \mathrm{~min}$ at $37^{\circ} \mathrm{C}$. This was followed by post-fixation (30 $\mathrm{min}$ in $4 \%$ paraformaldehyde-PBS), acetylation (10-min treatment in $0.25 \%$ acetic anhydride in $0.1 \mathrm{M}$ triethanolamine, $\mathrm{pH}$ 8.0) and dehydration in ethanol. After drying the sections, $70 \mu \mathrm{l}$ sense or antisense RNA probes (20000 c.p.m. labeled $\mathrm{RNA} / \mu \mathrm{l}$ in $50 \%$ formamide, $0.3 \mathrm{M} \mathrm{NaCl}, 20 \mathrm{mM}$ Tris $\mathrm{HCl}$ (pH 8.0), $5 \mathrm{mM}$ EDTA, $100 \mathrm{mM}$ DTT, $0.5 \mathrm{mg}$ tRNA $/ \mathrm{ml}, 1 \times$ Denhardt's solution and $10 \%$ dextran 
sulfate) were applied to the tissues. Coverslips were added and the slides were incubated at $60{ }^{\circ} \mathrm{C}$ overnight.

The sections were then washed with $4 \times \mathrm{SSC}$ and $10 \mathrm{mM}$ DTT four times for $15 \mathrm{~min}$ each, followed by a stringent wash for $30 \mathrm{~min}$ at $60{ }^{\circ} \mathrm{C}$ in $50 \%$ formamide, $0 \cdot 15 \mathrm{M} \mathrm{NaCl}, 30 \mathrm{mM}$ Tris $\mathrm{HCl}, 5 \mathrm{mM}$ EDTA, $\mathrm{pH} 8 \cdot 0$. Thereafter the sections were treated with RNase A solution $(20 \mu \mathrm{g} / \mathrm{ml})$ for $30 \mathrm{~min}$ at $37^{\circ} \mathrm{C}$, washed for $15 \mathrm{~min}$ in $2 \times \mathrm{SSC}$ at $60^{\circ} \mathrm{C}$ and $15 \mathrm{~min}$ in $0 \cdot 1 \times \mathrm{SSC}$ at $60^{\circ} \mathrm{C}$ and then dehydrated with ethanol and air dried. The slides were then dipped in NTB2 emulsion (Eastman Kodak, Rochester, NY, USA; diluted $1: 1$ in $0.6 \mathrm{M}$ ammonium acetate), and exposed in the dark at $4{ }^{\circ} \mathrm{C}$ for 15 days. The slides were then developed at $12{ }^{\circ} \mathrm{C}$ by treating with D-19 solution (Eastman Kodak) for $2.5 \mathrm{~min}$, rinsed in distilled water, fixed for $5 \mathrm{~min}$ in Unifix (Eastman Kodak), and finally rinsed for $5 \mathrm{~min}$ in distilled water. Nuclei were further stained with Hoechst 33258 (Sigma), after which the slides were mounted with glycergel (DAKO A/S, Glostrup, Denmark). Hybridization with a sense probe was used as a control and no hybridization signals were detected in any of the tissues analyzed.

\section{RESULTS}

By using Northern analysis, two mouse 17HSD type 2 mRNA transcripts $(0.9$ and $1.2 \mathrm{~kb})$ are detected with a constant ratio in various tissues. Sequencing results of several cDNA clones from a liver library indicate that the predominant form, the $0.9 \mathrm{~kb}$ mRNA, codes for the full length functional protein (Mustonen et al. 1997). Both of the mouse mRNAs are identically detected by a cDNA corresponding to the RNA-probe used in the present study (nucleotides 584-1320 of the cDNA) as well as with a full length cDNA probe (data not shown). All this information indicates that the present study reports the cellular localization of two functional mouse 17HSD type 2 mRNAs. Furthermore, our previous results on the tissue distribution of the mRNAs agree with the present data obtained with in situ hybridization. In line with our previous Northern analyses (Mustonen et al. 1997), type 2 mRNA was detected in several epithelial cell layers of the gastrointestinal and urogenital tracts of both male and female mice, including absorbtive and secretory epithelium as well as protective epithelium. No 17HSD type 2 expression was found in connective tissues or muscle cell layers in any of the tissue specimens analyzed. Neither was mRNA expression detected in any parts of the respiratory system, including epithelial cells of the trachea and bronchi, or in the respiratory epithelium of alveolar sacs. Furthermore, 17HSD type $2 \mathrm{mRNA}$ was not detected in any of the cell types present in the pancreas, spleen, heart, brain or adrenals, in which signals obtained with antisense probe were indistinguishable from those found by hybridizing with the sense probe (data not shown).

\section{Male and female gastrointestinal tract and liver}

The localization and intensity of 17HSD type 2 mRNA expression were identical in the gastrointestinal tracts of both male and female mice. The mRNA was expressed in several epithelial cell types throughout the gastrointestinal tract. Strong expression of the mRNA was detected in the stratified squamous epithelium of the esophagus, both in the thoracic area (Fig. 1A) and at the esophago-gastric junction (Fig. 1B). Moderate mRNA expression was found in the surface epithelial cells of the stomach (Fig. 1C and D), while gastric glands did not show prominent expression. The mRNA for 17 HSD type 2 was also strongly expressed in the surface epithelium of the small intestine (Fig. 1E) and colon (Fig. 1F), in which the highest expression was seen at the tips of mucosal villi. Interestingly, expression of the mRNA gradually increased towards the tips of the villi. No expression was found in the lamina propria or the muscularis mucosae, or the submucosal layers of the esophagus, stomach or intestine.

The hepatocytes, which develop from the endodermal epithelium during embryogenesis, showed equally strong expression of 17HSD type 2 mRNA in both male and female mice (Fig. $1 \mathrm{G}$ and $\mathrm{H}$ ). In addition, the mucosal epithelium of the gall bladder showed slight expression of the mRNA (Fig. 1I).

\section{Male and female urogenital tract}

In both male and female kidneys, the mRNA was detected predominantly in deep layers of the cortex and outer medulla (cortico-medullary junction), most probably corresponding to the thick descending and/or ascending limbs of the loops of Henle (Fig. 2A). No expression was found in the renal corpuscles or in the collecting tubules of the medulla. The transitional epithelium of the urinary bladder showed a strong hybridization signal for 17HSD type 2 mRNA in both male and female mice (Fig. 2B). However, the connective tissue and the muscle cell layers did not show any expression for the enzyme.

Among the male reproductive organs, heterogeneous expression of 17HSD type 2 mRNA was 

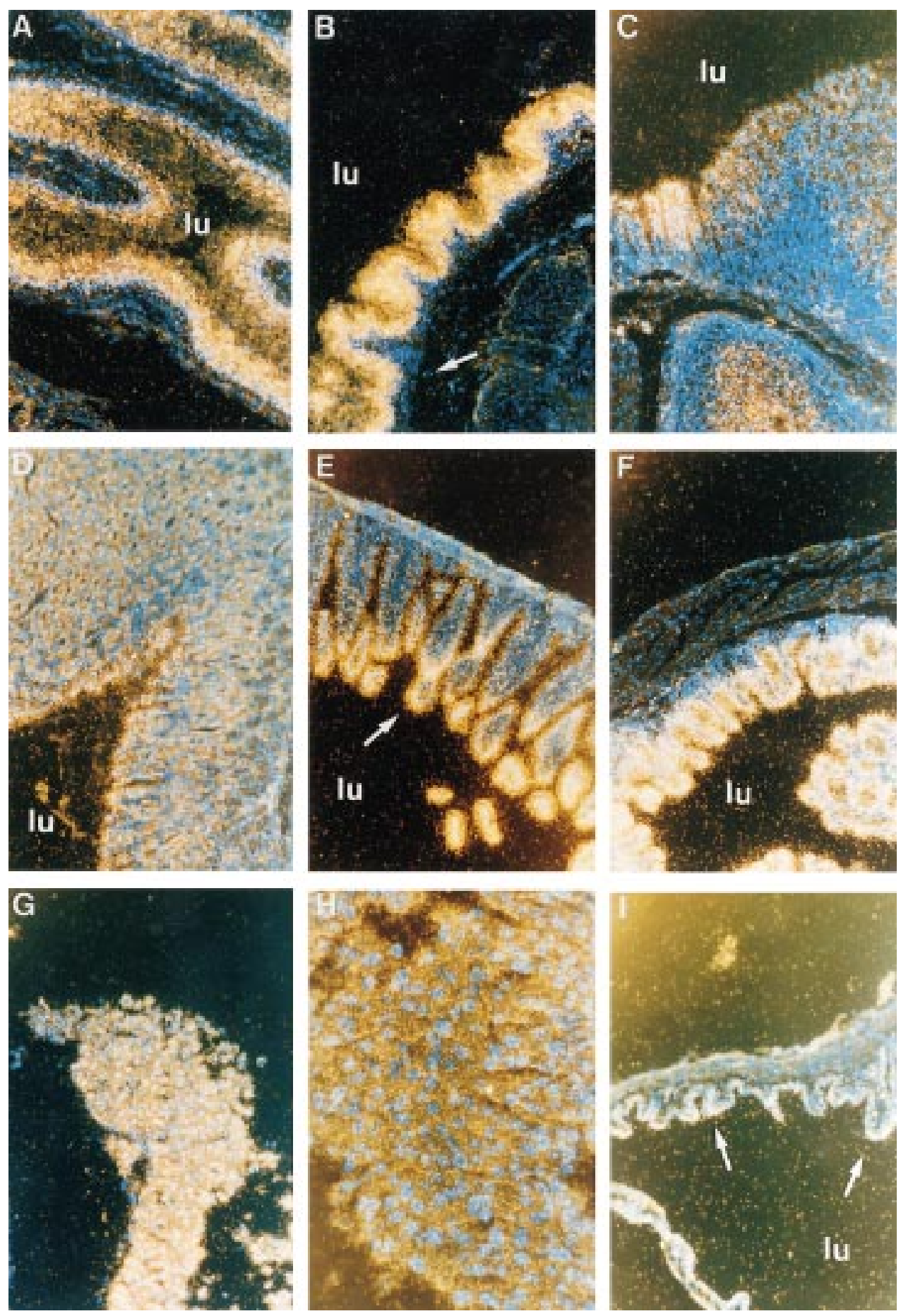

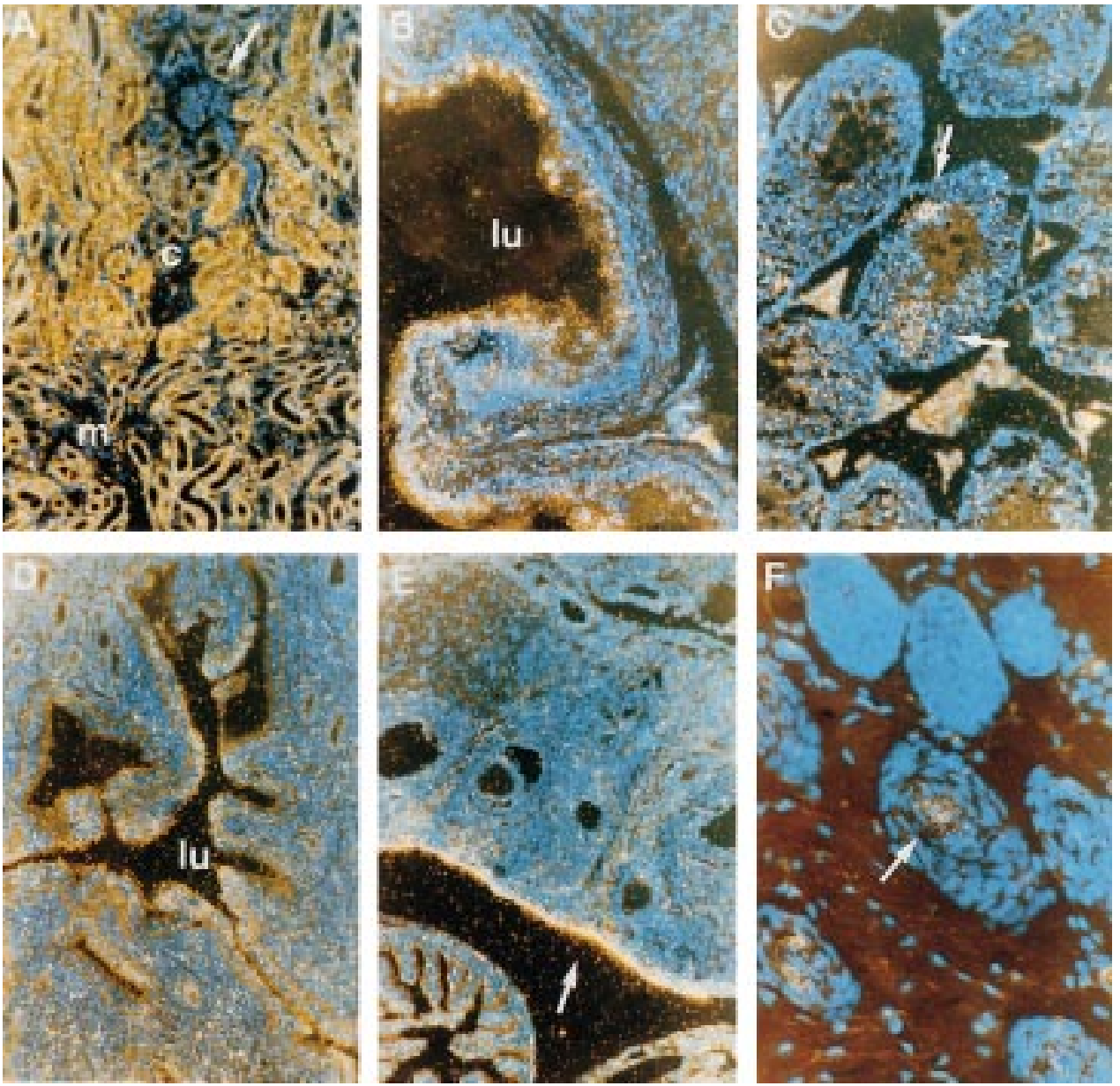

FIGURE 2. Darkfield microscope images of the urogenital tract and skin, showing hybridization signals for $17 \mathrm{HSD}$ type 2. (A) In kidney the mRNA was expressed moderately in the corticomedullary junction, i.e. in the thick descending and/or ascending limbs of the loops of Henle, but no expression was found in the collecting tubules of the medulla $(\mathrm{m})$ or in the proximal tubules of the cortex (c) (arrow=glomerulus). (B) The epithelium of the urinary bladder showed a strong hybridization signal for $17 \mathrm{HSD}$ type $2 \mathrm{mRNA}$. (C) Heterogeneous expression of 17HSD type 2 mRNA was seen in the seminiferous tubules (arrows) of testes. (D) The mRNA for type 2 was only slightly expressed in uterine epithelial cells. (E) In the ovary, significant expression was found only in surface epithelial cells (arrow). (F) The enzyme was also expressed in the sebaceous glands of the skin (arrow). Magnification: A-E $\times 160 ; \mathrm{F} \times 400$; nuclei were stained with Hoechst 33258 (blue color), lu=lumen.

FIGURE 1. Darkfield microscope images of the gastrointestinal tissues and liver of male mice, showing hybridization signals for 17HSD type 2. (A) A strong signal was detected in the stratified squamous epithelium of the thoracic esophagus. (B) mRNA signal in the esophagus was strongest near the esophago-gastric junction (arrow). (C and D) In surface epithelial cells of the stomach, the strongest expression was detected on the luminal surface, while no signal was detected in the muscle cell layers (lower right corner in Fig. C). (E) The mRNA for 17HSD type 2 was strongly expressed in the epithelial cells of mucosal villi of the small intestine. Expression of the mRNA increases gradually towards the tips of the villi (arrow). (F) Strong expression of the mRNA was also detected in epithelial cells of the colon. ( $\mathrm{G}$ and $\mathrm{H}$ ) A strong signal for $17 \mathrm{HSD}$ type 2 was seen in hepatocytes. (I) The mucosal epithelial cells of the gall bladder showed only weak expression of the mRNA (arrows). Magnification: A-G, I × 160; H $\times 400$; nuclei were stained with Hoechst 33258 (blue color), lu=lumen. 
detected in approximately $30 \%$ of the seminiferous tubules (Fig. 2C), suggesting that the enzyme is expressed either in developing sperm cells or in Sertoli cells. No detectable expression was found in the interstitial space (Leydig cells), or in any cell types of the epididymis, seminal vesicle or prostate. In females, the mRNA was slightly expressed in uterine epithelial cells (Fig. 2D). In the ovary, low expression was found in surface epithelial cells (Fig. 2E), and none in granulosa or theca cells at any stage of follicular development. Similarly, the mRNA was not detectable in corpora lutea.

\section{Male and female skin}

Expression of the mRNA was analyzed in female and male skin, and it was found exclusively only in sebaceous glands (Fig. 2F).

\section{DISCUSSION}

The substrate specificity of 17HSD type 2 is not fully characterized, but the data available indicate that the enzyme efficiently inactivates $\mathrm{E} 2, \mathrm{~T}$ and DHT into their corresponding inactive 17-keto forms (Wu et al. 1993, Akinola et al. 1996, Elo et al. 1996, Miettinen et al. 1996, Mustonen et al. 1997), while the opposite reductive reaction is not catalyzed by the enzyme. In line with its enzymatic activity, the present results indicate that the enzyme is not expressed in ovarian follicles or testicular Leydig cells, but it is detectable in ovarian surface epithelial cells and in the seminiferous tubules of the testis. Based on these results, together with those of other recent studies (Wu et al. 1993, Geissler et al. 1994, Akinola et al. 1996, Miettinen et al. 1996, Mustonen et al. 1997), it is evident that the enzyme does not significantly contribute to E2 and T biosynthesis. However, using RT-PCR, low amounts of 17HSD type 2 mRNA have been detected in human corpora lutea (Zhang et al. 1996).

17HSD type 2 was initially cloned from a human prostate library by using an expression cloning technique with $\mathrm{T}$ as a substrate (Wu et al. 1993). Northern analyses have, furthermore, shown that, of the sex steroid target tissues, the enzyme is expressed at least in benign and malignant human prostate (Wu et al. 1993, Delos et al. 1995, Elo et al. 1996), and in normal human endometrium (Casey et al. 1994, Miettinen et al. 1996). Previous data suggest that in both human endometrium and prostate the enzyme appears to be present in the epithelial cells (Casey et al. 1994, Delos et al. 1995). In line with the results of these studies, the enzyme has also been detected in certain epithelial-like cancer cell lines originating from these tissues (Miettinen et al. 1996). It is likely therefore, that the enzyme down-regulates sex steroid action locally in the target tissues by inactivating circulating 17 hydroxysteroids into their inactive 17-keto forms (Casey et al. 1994, Elo et al. 1996, Miettinen et al. 1996). However, our recent Northern analyses have shown that the enzyme is only slightly expressed in rodent prostate and uterus (Akinola et al. 1996, Mustonen et al. 1997). This, together with the results of the present study, suggests a difference between humans and rodents in 17HSD type 2 expression in the genital tract.

Compared with the uterus and prostate, stronger expression of 17HSD type $2 \mathrm{mRNA}$ is found in several human and rodent tissues which are not considered as classical steroid hormone target tissues, including intestine, liver, kidney and brain (Casey et al. 1994, Akinola et al. 1996, Miettinen et al. 1996, Mustonen et al. 1997). In the present study, strong expression of the mRNA was localized in the epithelium of the esophagus, stomach, small intestine, colon, urinary bladder and thick descending and/or ascending limbs of the loops of Henle in the kidney, as well as in hepatocytes. By using Northern analyses, 17HSD type 2 mRNA expression has been previously detected also in the brain as well as in adrenals (Carsol et al. 1996, Mustonen et al. 1997). However, in the present in situ hybridization study, the mRNA could not be detected in any of the sections obtained from different areas of the brain and adrenals. This suggests a low homogenous expression of the mRNA throughout these tissues. Our recent Northern analyses indicated that in the rat, 17HSD type $2 \mathrm{mRNA}$ is similarly expressed in both male and female liver and small intestine, from late fetal life to 6-week-old animals (Akinola et al. 1997). This, together with the present findings, indicates that there are no differences in 17HSD type 2 expression in the various epithelial cell types in male and female mice. The data, therefore, suggest constitutive expression of the enzyme in the gastrointestinal tract, and that 17HSD type 2 expression is not related to the concentration or type of sex steroid in the blood circulation. However, estrogen receptors, but not androgen receptors, have been localized in many of the cell types of the gastrointestinal and urinary tracts expressing 17HSD type 2 (Riuzeweld de Winter et al. 1991, Pacchioni et al. 1993, Thomas et al. 1993), and additional studies are needed in order to characterize the role of 17HSD type 2 in the regulation of sex steroid action locally in the different cell types of the gastrointestinal tract. 
The expression of 17HSD type 2 in several luminal epithelial cell types in both the gastrointestinal and urinary tracts suggests that the enzyme could have a role in inactivating sex steroids and steroid-like compounds found in the intestinal contents. It is well known that orally administered $\mathrm{E} 2$ and $\mathrm{T}$ are readily inactivated, and do not enter the blood circulation in significant amounts. Hence, it is likely that 17HSD type 2 is one of the enzymes involved in the rapid degradation and excretion of steroids in surface epithelial cells and hepatocytes in the intestine and liver respectively.

17HSD type 2 is one of the short chain dehydrogenases/reductases (SDR). In the family of SDR-enzymes, 17HSD type 2 has the highest identity $(45 \%)$ with $11 \beta$-HSD (11HSD) type 2 (Baker 1995, Brown et al. 1996). The 11HSD type 2 enzyme possesses a predominant oxidative activity inactivating cortisol (11 $\beta$-hydroxy) to cortisone (11-keto), and the activity of the enzyme has been shown to be crucial for aldosterone action in mineralocorticoid target tissues (Edwards et al. 1988, Funder et al. 1988, Mune et al. 1995). It has been suggested that the 11HSD and 17HSD type 2 enzymes have sufficiently conserved their tertiary structures such that 17HSD type 2 could also metabolize a corticosteroid (Baker 1995). Interestingly, the cellular distribution shown for 11HSD type 2 (Roland \& Funder 1996, Smith et al. 1996) is very close to that resolved for 17HSD type 2 in the present study. However, in cultured cells, cortisol does not affect the E2 to E1 conversion catalyzed by 17HSD type 2 (data not shown), indicating that the putative 11HSD activity of the enzyme is not significant compared with its 17HSD activity. As $\mathrm{E} 2$ and $\mathrm{T}$ have not been shown to possess any significant affinity towards mineralocorticoid receptors (Arriza et al. 1987, Alnemri et al. 1991), the physiological role, if any, of $17 \mathrm{HSD}$ type 2 in mineralocorticoid target tissues remains to be characterized. In conclusion, the localization of 17HSD type 2 in several surface epithelial cells of the gastrointestinal and urinary tracts suggests a role for the enzyme in steroid inactivation in a range of tissues and cell types not considered as classical sex steroid target tissues.

\section{ACKNOWLEDGEMENTS}

We thank Ms Liisa Kaarela and Ms Eeva Holopainen for their expert technical assistance. This work was supported by the Research Council for Health of the Academy of Finland (Project no. 3314). The Department of Clinical Chemistry is a World Health Organization Collaborating Center for Research in Human Reproduction supported by the Ministries of Education, Social Affairs and Health, and Foreign Affairs, Finland.

\section{REFERENCES}

Adamski J, Normand T, Leenders F, Monté D, Begue A, Stéhelin D, Jungblut PW \& de Launoit Y 1995 Molecular cloning of a novel widely expressed human $80 \mathrm{kDa}$ $17 \beta$-hydroxysteroid dehydrogenase IV. Biochemical fournal $311437-443$.

Akinola L, Poutanen M \& Vihko R 1996 Cloning of rat $17 \beta$-hydroxysteroid dehydrogenase type 2 and characterization of tissue distribution and catalytic activity of rat type 1 and type 2 enzymes. Endocrinology 137 1572-1579.

Akinola LA, Poutanen M, Vihko R \& Vihko P 1997 Expression of $17 \beta$-hydroxysteroid dehydrogenase type 1 and type 2 , P450 aromatase, and $20 \alpha$-hydroxysteroid dehydrogenase enzymes in immature, mature, and pregnant rats. Endocrinology 138 2886-2892.

Alnemri ES, Maksymowych AB, Robertson NM \& Litwack G 1991 Overexpression and characterization of the human mineralocorticoid receptor. Fournal of Biological Chemistry 266 18072-18081.

Andersson S, Geissler WM, Wu L, Davis DL, Grumbach MM, New MI, Schwarz HP, Blethen SL, Mendonca BB, Bloise W, Witchel SF, Cutler GB, Griffin JE, Wilson JD \& Russell DW 1996 Molecular genetics and pathophysiology of $17 \beta$-hydroxysteroid dehydrogenase 3 deficiency. Fournal of Clinical Endocrinology and Metabolism 81 130-136.

Arriza JL, Weinberger C, Cerelli G, Glaser TM, Handelin BL, Housman DE \& Evans RM 1987 Cloning of human mineralocorticoid receptor complementary DNA: structural and functional kinship with the glucocorticoid receptor. Science 237 268-275.

Baker ME 1995 Unusual evolution of $11 \beta$ - and $17 \beta$-hydroxysteroid and retinol dehydrogenases. BioEssays 18 63-70.

Brown RW, Chapman KE, Kotelevtsev Y, Yau JLW, Lindsay RS, Brett L, Leckie C, Murad P, Lyons V, Mullins JJ, Edwards CRW \& Seckl JR 1996 Cloning and production of antisera to human placental $11 \beta$-hydroxysteroid dehydrogenase type 2. Biochemical fournal 313 1007-1017.

Carsol J-L, Adamski J, Guirou O, Gérard H, Martin P-M \& de Launoit Y 1996 17 $\beta$-hydroxysteroid dehydrogenase activity correlates with the type-2 $17 \beta$-hydroxysteroid dehydrogenase mRNA abundance in human meningioma tumors. Neuroendocrinology 64 70-78.

Casey ML, MacDonald PC \& Andersson S 1994 $17 \beta$-hydroxysteroid dehydrogenase type 2 : chromosomal assignment and progestin regulation of gene expression in human endometrium. Fournal of Clinical Investigation 94 2135-2141.

Chotteau-Lelievre A, Desbiens X, Pelczar H, Defossez P-A \& de Launoit Y 1997 Differential expression patterns of the PEA3 group transcription factors through murine embryonic development. Oncogene 15 937-952.

Delos S, Carsol JL, Chazarossian E, Raynaud JP \& Martin PM 1995 Testosterone metabolism in primary cultures of human prostate epithelial cells and fibroblasts. Fournal of Steroid Biochemistry and Molecular Biology 55 375-383.

Deyashiki Y, Ohshima K, Nakanishi M, Sato K, Matsuura K \& Hara A 1995 Molecular cloning and characterization of mouse estradiol $17 \beta$ dehydrogenase (A-specific), a member of the aldoketoreductase family. Fournal of Biological Chemistry 270 10461-10467. 
Dieuaide-Noubhani M, Novikov D, Baumgart E, Vanhooren JCT, Fransen M, Goethals M, Vandekerckhove J, Van Veldhoven PP \& Mannaerts GP 1996 Further characterization of the peroxisomal 3-hydroxyacyl-CoA dehydrogenases from rat liver. Relationship between the different dehydrogenases and evidence that fatty acids and the $\mathrm{C}_{27}$ bile acids di- and tri-hydroxycoprostanic acids are metabolized by separate multi functional proteins. European Fournal of Biochemistry 240 660-666.

Edwards CR, Stewart PM, Burt D, Brett L, McIntyre MA, Sutanto WS, de Kloet ER \& Monder C 1988 Localization of 11-beta-hydroxysteroid dehydrogenase: tissue specific protector of the mineralocorticoid receptor. Lancet 2 986-989.

Elo JP, Akinola LA, Poutanen M, Vihko P, Kyllönen AP, Lukkarinen O \& Vihko R 1996 Characterization of $17 \beta$-hydroxysteroid dehydrogenase isoenzyme expression in benign and malignant human prostate. International Fournal of Cancer 66 37-41.

Funder JW, Pearce PT, Smith R \& Smith AIX 1988 Mineralocorticoid action: target tissue specificity of enzyme, not receptor, mediated. Science 242 583-585.

Geissler WM, Davis DL, Wu L, Bradshaw KD, Patel S, Mendoca BB, Elliston KO, Wilson JD, Russell DW \& Andersson S 1994 Male pseudohermaphroditism caused by mutations of testicular 17 $\beta$-hydroxysteroid dehydrogenase 3 . Nature Genetics 7 34-39.

Ghersevich S, Nokelainen P, Poutanen M, Orava M, Autio-Harmainen H, Rajaniemi H \& Vihko R 1994a Rat $17 \beta$-hydroxysteroid dehydrogenase type 1 : primary structure and regulation of enzyme expression in rat ovary by diethylstilbestrol and gonadotropins in vivo. Endocrinology 135 1477-1487.

Ghersevich S, Poutanen M, Tapanainen J \& Vihko R $1994 b$ Hormonal regulation of rat $17 \beta$-hydroxysteroid dehydrogenase type 1 in cultured rat granulosa cells: effects of recombinant follicle-stimulating hormone, estrogens, androgens, and epidermal growth factor. Endocrinology 135 1963-1971.

Leenders F, Adamski J, Husen B, Thole HH \& Jungblut PW 1994 Molecular cloning and amino acid sequence of the porcine $17 \beta$-estradiol dehydrogenase. European Fournal of Biochemistry 222 221-227.

Miettinen MM, Mustonen MVJ, Poutanen MH, Isomaa VV \& Vihko RK 1996 Human 17ß-hydroxysteroid dehydrogenase type 1 and type 2 isoenzymes have opposite activities in cultured cells and characteristic cell- and tissue-specific expression. Biochemical Fournal 314 839-845.

Mune T, Rogerson FM, Nikkilö H, Agarwal AK \& White PC 1995 Human hypertension caused by mutations in the kidney isoenzyme of $11 \beta$-hydroxysteroid dehydrogenase. Nature Genetics 10 394-399.

Mustonen MVJ, Poutanen MH, Isomaa VV, Vihko PT \& Vihko RK 1997 Cloning of mouse 17ß-hydroxysteroid dehydrogenase type 2 , and analyzing expression of the mRNAs for types 1, 2, 3, 4 and 5 in mouse embryos and adult tissues. Biochemical fournal 325 199-205.

Nokelainen P, Puranen T, Peltoketo H, Orava M, Vihko P \& Vihko R 1996 Molecular cloning of mouse 17 $\beta$-hydroxy- steroid dehydrogenase type 1 and characterization of enzyme activity. European Fournal of Biochemistry 236 482-490.

Normand T, Husen B, Leenders F, Pelczar H, Baert J-L, Begue A, Flourens A-C, Adamski J \& de Launoit Y 1995 Molecular characterization of mouse $17 \beta$-hydroxysteroid dehydrogenase IV. Fournal of Steroid Biochemistry and Molecular Biology 55 541-548.

Pacchioni D, Papotti M, Andorno E, Bonino F, Mondardini A, Oliveri F, Brunetto M, Bussolati G \& Negro F 1993 Expression of estrogen receptor $\mathrm{mRNA}$ in tumorous and non-tumorous liver tissue as detected by in situ hybridization. Fournal of Surgical Oncology 3 14-17.

Peltoketo H, Isomaa V \& Vihko R 1988 Complete amino acid sequence of human placental $17 \beta$-hydroxysteroid dehydrogenase deduced from cDNA. FEBS Letters 239 73-77.

Poutanen M, Isomaa V, Peltoketo H \& Vihko R 1995 Role of $17 \beta$-hydroxysteroid dehydrogenase type 1 in endocrine and intracrine estradiol biosynthesis. Fournal of Steroid Biochemistry and Molecular Biology 55 525-532.

Qin Y-M, Poutanen MH, Helander HM, Kvist A-P, Siivari KM, Schmitz W, Conzelmann E, Hellman U \& Hiltunen K 1997 Peroxisomal multi functional enzyme of $\beta$-oxidation metabolizing D-3-hydroxyacyl-CoA esters in rat liver: molecular cloning, expression and characterization. Biochemical Fournal 321 21-28.

Riuzeweld de Winter JA, Trapman J, Vermey M, Mulder E, Zegers ND \& Van der Kwast TH 1991 Androgen receptor expression in human tissues: an immunohistochemical study. Fournal of Histochemistry and Cytochemistry 39 927-936.

Roland BL \& Funder JW 1996 Localization of $11 \beta$-hydroxysteroid dehydrogenase type 2 in rat tissues: in situ studies. Endocrinology 137 1123-1128.

Sha J, Baker P \& O'Shaughnessy PJ 1996 Both reductive forms of $17 \beta$-hydroxysteroid dehydrogenase (types 1 and 3 ) are expressed during development in the mouse testis. Biochemical and Biophysical Research Communications 222 90-94.

Smith RE, Maguire JA, Stein-Oakley AN, Sasano H, Takahashi K-I, Fukushima K \& Krozowski ZS 1996 Localization of $11 \beta$-hydroxysteroid dehydrogenase type 2 in human epithelial tissues. Fournal of Clinical Endocrinology and Metabolism 81 3244-3248.

Thomas ML, Xu X, Norfleet AM \& Watson CS 1993 The presence of functional estrogen receptors in intestinal epithelial cells. Endocrinology 132 426-430.

Wu L, Einstein M, Geissler WM, Chan HK, Elliston KO \& Andersson S 1993 Expression cloning and characterization of human $17 \beta$-hydroxysteroid dehydrogenase type 2 , a microsomal enzyme possessing $20 \alpha$-hydroxysteroid dehydrogenase activity. Fournal of Biological Chemistry 268 12964-12969.

Zhang Y, Word RA, Fesmire S, Carr BR \& Rainey WE 1996 Human ovarian expression of $17 \beta$-hydroxysteroid dehydrogenase types 1,2 and 3. Fournal of Clinical Endocrinology and Metabolism 81 3594-3598.

RECEIVED 10 July 1997 